\title{
Desain dan Pengembangan Aplikasi Sistem Informasi Administrasi Desa
}

\author{
Paulus Lucky Tirma Irawan ${ }^{1 *}$, Yudhi Kurniawan ${ }^{1}$, dan Windra Swastika ${ }^{1}$ \\ ${ }^{1}$ Program Studi Teknik Informatika, Universitas Ma Chung, Jl. Villa Puncak Tidar N-1 Malang \\ *Email korespondensi: paulus.lucky@machung.ac.id
}

\begin{abstract}
Abstrak
Desa Tegalweru terletak di kecamatan Dau, Kabupaten Malang. Dalam hal pengelolaan data administratif, Desa Tegalweru dibantu oleh beberapa perangkat desa. Salah satu rutin administratif yang berkaitan langsung dengan layanan masyarakat adalah kegiatan surat menyurat. Berdasarkan analisa tahap awal ditemukan beberapa potensi masalah, seperti kurang efektifnya proses pengelolaan rutin administratif karena data kependudukan yang menjadi data pendukung utama harus diakses secara manual. Permasalahan ini perlu untuk mendapatkan perhatian khusus sehingga Desa Tegalweru dapat meminimalisir kesalahan-kesalahan yang dapat terjadi sekaligus meningkatkan layanannya. Pemanfaatan teknologi informasi dapat menjadi salah satu solusi untuk mengatasi permasalahan yang ditemukan. Pada penelitian ini akan dilakukan analisa kebutuhan untuk menentukan spesifikasi dan model kerja sistem, yang kemudian dilanjutkan dengan pengembangan dan pengujian aplikasi hingga penerapan aplikasi di Desa Tegalweru sendiri. Aplikasi yang akan dikembangkan berbentuk sistem informasi administrasi berbasis web.
\end{abstract}

Kata Kunci: Aplikasi, Administrasi, Sistem Informasi, Surat

\begin{abstract}
Tegalweru is located in Dau, Malang. In data management, Tegalweru is assisted by a number of village officials. One routine administration that is directly related to community service is correspondence activities. Based on the initial analysis of the findings in the field, there are several potential problems found. The absence of a system makes the administrative routine management process less effective because population data that is the main supporting data must be accessed manually. This problem needs to get more attention so that Tegalweru can minimize the mistakes that occur due to the administrative process carried out manually and also to improve its services. Utilization of information technology can be one solution to overcome the problems found. Requirements analysis to determine the system working specifications and models will be done; continued with the development, testing and implementation of the applications in Desa Tegalweru. In this research, a web-based information system would be developed.
\end{abstract}

Keywords: Application, Administration, Certificate, Information System

Format Sitasi: Irawan PLT, Kurniawan, Y \& Swastika, W. (2019). Desain dan Pengembangan Aplikasi Sistem Informasi Administrasi Desa. Jurnal Solma, 8(2), 181-192. Doi: http://dx.doi.org/10.29405/solma.v8i2.3088

Diterima: 14 Februari 2019 | Revisi: 02 Oktober 2019 | Dipublikasikan: 21 Oktober 2019

(C) 2019. Oleh authors. Lisensi Jurnal Solma, LPPM-Uhamka, Jakarta. Artikel ini bersifat open access yang didistribusikan di bawah syarat dan ketentuan Creative Commons Attribution (CC-BY) license. (http://creativecommons.org/licenses/by/4.0/) 


\section{PENDAHULUAN}

Desa Tegalweru terletak di Kecamatan Dau, Kabupaten Malang. Desa dengan 1043 Kartu Keluarga ini memiliki jumlah penduduk kurang lebih 3622 orang (data kependudukan Desa, November 2018). Desa Tegalweru memiliki 3 dusun, meliputi dusun Krajan, dusun Kraguman dan dusun Jengglong. Dusun Krajan memiliki area yang paling besar, sehingga dalam pengelolaannya wilayah Krajan dibagi ke dalam 3 wilayah yang lebih kecil, mulai dari dusun Krajan wilayah 1, dusun Krajan wilayah 2 dan dusun Krajan wilayah 3. Kantor Desa Tegalweru terletak di jalan Brawijaya no. 90, Desa Tegalweru, 65151.

Proses pengelolaan data di Desa Tegalweru dilakukan oleh beberapa perangkat desa yang terdiri dari Kaur (Kepala Urusan) Umum, Kaur Keuangan, Kebayan, Kuwono, Modin, Pramu, Kepetengan dan Kamituwo. Masing-masing perangkat memiliki tugas pokoknya masing-masing diatur di dalam UUD NO. 6 Tahun 2014, tentang Pemerintahan Desa pasal 48 yang pelaksanaannya diatur dalam Peraturan Pemerintah Tahun 2014. Kegiatan administratif desa lebih sering melibatkan perangkat Kebayan dan Modin. Perangkat Kebayan memiliki tugas pokok dibidang administrasi kependudukan, adminsitrasi pertanahan, urusan transmigrasi dan monografi desa. Modin salah satu tugas pokoknya adalah mengadakan pencatatan pengurusan kematian termasuk segala sesuatu yang berkaitan dengan permasalahan kematian tersebut, serta pendataan tentang nikah talak rujuk.

Kegiatan administratif yang berkaitan langsung dengan layanan masyarakat adalah kegiatan surat menyurat. Hasil temuan di lapangan, pelaksanaannya hanya ditangani oleh seorang perangkat saja (Kebayan) sehingga proses pembuatan surat cukup memakan waktu. Belum lagi, surat-surat yang sudah diregister hanya diarsip secara manual menggunakan file excel dan buku catatan (log book). Hingga saat ini Desa Tegalweru belum menggunakan aplikasi sistem informasi yang secara khusus digunakan untuk membantu proses pengelolaan administratif. Pemanfaatan sistem informasi yang didukung oleh teknologi informasi dapat membantu para aparatur desa dalam melaksanakan kegiatan tata kelola administratif desa untuk mewujudkan good government governance (Anwar \& Pratolo, 2013). 


\section{MASALAH}

Analisa tahap awal terhadap rutin admisnitratif di Desa Tegalweru, terdapat beberapa potensi masalah yang ditemukan seperti terlihat pada tabel 1 .

Tabel 1. Potensi Permasalahan Administratif

\begin{tabular}{|c|c|c|c|}
\hline No & Masalah & Dampak & Usulan Solusi \\
\hline 1 & $\begin{array}{l}\text { Data administratif ditangani secara } \\
\text { manual dan terpisah (file excel, } \\
\text { logbook manual) }\end{array}$ & $\begin{array}{l}\text { Data tidak konsisten, data } \\
\text { tidak akurat, rawan rusak } \\
\text { dan hilang }\end{array}$ & Sistem Aplikasi \\
\hline 2 & $\begin{array}{l}\text { Perangkat Desa hanya terfokus } 1 \\
\text { orang }\end{array}$ & efektifitas layanan rendah & $\begin{array}{c}\text { Administrasi Desa } \\
\text { terintegrasi }\end{array}$ \\
\hline 3 & $\begin{array}{l}\text { Proses manual memakan waktu yang } \\
\text { cukup lama }\end{array}$ & $\begin{array}{l}\text { efisiensi layanan rendah, } \\
\text { proses lama }\end{array}$ & \\
\hline
\end{tabular}

Potensi-potensi masalah pada tabel 1. perlu untuk mendapatkan perhatian khusus sehingga Desa Tegalweru dapat meminimalisir kesalahan-kesalahan yang sering dialami serta meningkatkan layanannya kepada masyarakat melalui pembuatan aplikasi sistem informasi (Andoyo \& Sujarwadi, 2017). Hal ini juga sudah diatur dalam UU Desa yang mengharapkan peran serta aktif para aparatur desa untuk mendukung proses pembangunan desa berbasis Internet dengan melibatkan para praktisi teknologi informasi (Badri, 2016).

\section{METODE PELAKSANAAN}

Metode pelaksanaan kegiatan pengabdian kepada masyarakat ini dilakukan dalam beberapa tahapan. Untuk memberikan gambaran besar terhadap tahapan-tahapan yang dilalui dalam pengembangan aplikasi pada pelaksanaan kegiatan abdimas ini akan digunakan diagaram alir (Sommerville, 2011) sebagaimana terlihat pada gambar 1.

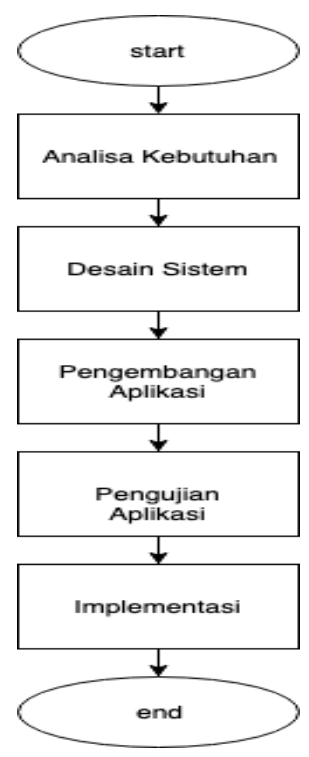

Gambar 1. Diagram Alir Pelaksanaan Abdimas 
Diagram alir sistem adalah peralatan perancangan sistem yang digunakan untuk menggambarkan proses sistem secara rinci untuk menggambarkan aliran sistem informasi dan diagram arus sistem untuk menggambarkan aliran program (Ladjamudin, 2013). Kegiatan diawali dengan tahapan analisa sistem, yaitu menjabarkan suatu sistem informasi yang utuh ke dalam bagian-bagian komponennya (Anwar \& Pratolo, 2013). Analisa sistem bertujuan untuk mengidentifikasikan dan mengevaluasi permasalahan, kesempatan, hambatan, dan kebutuhan untuk melakukan perbaikan (Jogiyanto, 2017). Setelah didapatkan desain sistem yang baik, kegiatan dilanjutkan dengan proses pengembangan dan pengujian aplikasi sebelum pada akhirnya diterapkan di lapangan. Tahap ini penting untuk memastikan bahwa sistem bebas dari kesalahan-kesalahan (Mulyanto, 2009).

Proses pengumpulan data dilakukan menggunakan teknik wawancara dan pengumpulan data-data fisik ke perangkat desa Kebayan dan Modin. Keterlibatan user terhadap pengembangan sebuah sistem informasi memiliki pengaruh yang besar terhadap hasil akhir dari sistem yang dibangun (Majid, Noor, Adnan, \& Mansor, 2010). Karena tanpa adanya keterlibatan dari user dalam pengembangan sebuah sistem, maka sistem tersebut akan sulit untuk mencapai hasil akhir yang diharapkan (Butt \& Ahmad, 2012). Setelah data-data didapatkan, kegiatan dilanjutkan dengan melakukan pembahasan terhadap beberapa usulan yang dapat menjadi alternatif solusi untuk menyelesaikan permasalahan yang ada.

Pengabdian kali ini bertujuan untuk mengembangkan sistem aplikasi yang memudahkan perangkat Desa dalam melakukan kegiatan administratif. Aplikasi yang dirancang terdiri dari 8 modul utama yang terbagi menjadi dua fokus utama yaitu data kependudukan dan data kepegawaian aparatur desa. Kegiatan dilanjutkan dengan mengimplementasikan desain-desain ke dalam bentuk aplikasi berbasis web yang terintegrasi basis data. Proses pengembangan dan pengujian dilakukan hampir bersamaan untuk memastikan setiap modul (modul testing) yang terlibat dapat bekerja dengan baik, sebelum dilakukan pengujian menyeluruh terhadap sistem yang dibangun (integration testing). Tahapan pengujian akan dilakukan pada lingkup pengembang (alpha testing) serta pengujian yang melibatkan pengguna akhir (beta testing). Setelah proses pengujian selesai, proses pelatihan penggunaan aplikasi akan diberikan. Pada tahapan ini diharapkan kesalahan sistem yang terjadi sudah diminimalisir sekecil mungkin.

Hasil seluruh rangkaian kegiatan yang sudah dilakukan kemudian akan didokumentasikan secara lengkap untuk kemudian dibuatkan laporan final serta persiapan 
pendaftaran hak cipta aplikasi. Oleh karena pendaftaran hak cipta aplikasi ini membutuhkan dokumentsasi lengkap penggunaan aplikasi sehingga sistem aplikasi yang dikembangkan harus dipastikan dapat berjalan secara baik terlebih dahulu.

\section{PEMBAHASAN}

Pemerintah daerah wajib mengembangkan sistem informasi desa sistem informasi desa dan pembangunan kawasan perdesaan (UU NO. 6 Tahun 2014). Sistem informasi desa meliputi data desa, data pembangunan desa, kawasan perdesaan, serta informasi lain yang berkaitan. Data tersebut dikelola oleh pemerintah desa dan dapat diakses oleh masyarakat desa serta semua pemangku kepentingan.

Pembuatan aplikasi yang sistematis dapat mengurangi faktor kesalahan manusia (human error) yang terjadi (Sutjianto, Noertjahyana, \& Rostianingsih, 2017). Lingkungan aplikasi yang user friendly dapat memudahkan proses pembuatan surat. Dengan adanya aplikasi ini, rutin administratif dapat dijalankan oleh siapa saja yang memiliki akses. Aplikasi sistematis juga akan memudahkan dalam penelusuran rekam jejak atau merekapitulasi hal yang diperlukan. Hasil analisa tahap awal terhadap potensi permasalahan yang muncul adalah keterbatasan tenaga dalam pengelolaan administratif serta ketiadaan sistem yang ditujukan untuk membantu rutin administratif tersebut.

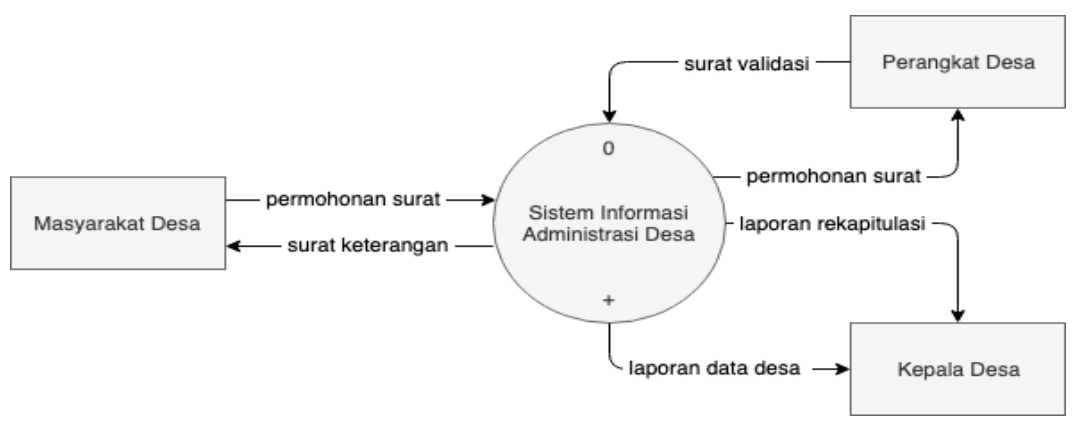

Gambar 2. Diagram arus data sistem informasi administrasi desa

Menilik kegiatan rutin administratif seperti yang ditunjukkan pada gambar 2. adalah layanan yang paling sering dibutuhkan oleh masyarakat, pembuatan sistem berbasis IT perlu dilakukan untuk mengatasi permasalahan yang ada sehingga Desa Tegalweru dapat meningkatkan produktifitasnya dalam memberikan layanan masyarakat. Diagram Arus Data memperlihatkan gambaran masukan-proses-keluaran suatu perangkat lunak, yaitu obyek-obyek data mengalir ke dalam perangkat lunak, kemudian ditransformasi oleh elemen-elemen pemrosesan yang menghasilkan data dari perangkat lunak (Pressman \& Roger, 2012). 


\section{Desain Fitur Aplikasi}

Bagian ini menjelaskan secara rinci fitur aplikasi yang sudah dirancang dan dikembangkan pada kegiatan pengabdian kepada masyarakat di desa Tegalweru.

1. Fitur User Login

Fitur User Login mengatur akses pengguna terhadap aplikasi sistem informasi administrasi Desa tegalweru. Pembagian tingkatan akses pada aplikasi ini (hingga saat ini) masih dibagi ke dalam 3 tingkatan pengguna, yakni superadmin, kepala desa, dan admin.

2. Fitur Manajemen password

Fitur manajemen password berfungsi untuk melakukan proses penggantian sandi yang digunakan untuk masuk ke dalam aplikasi sistem informasi. Fitur ini juga dapat memudahkan pengguna untuk melakukan proses recovery password jika terjadi kelalaian pengguna (lupa password).

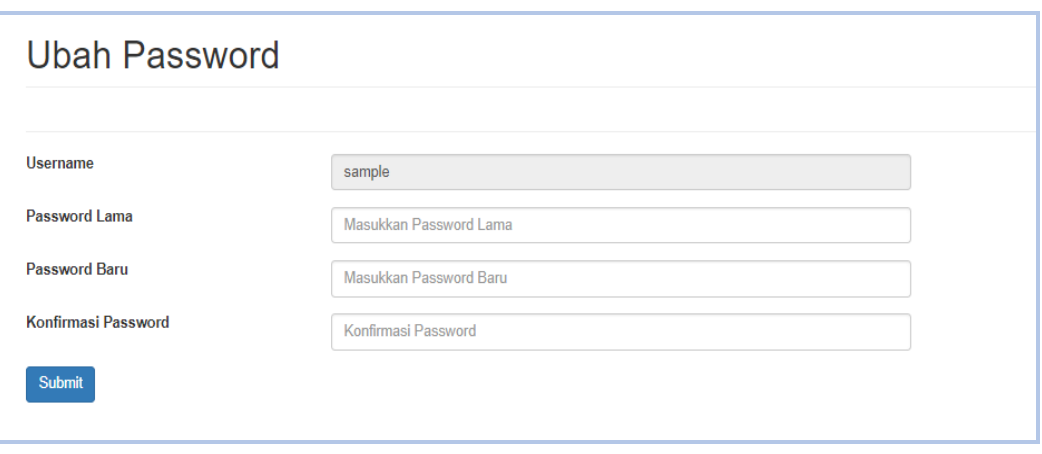

Gambar 3. Laman Manajemen Password

\section{Fitur Manajemen Data Grafik Kegiatan Administratif Desa}

Fitur ini memudahkan pengguna (Admin \& Kepala Desa) untuk mendapatkan gambaran kegiatan administratif yang sudah terjadi atau yang sedang berjalan pada periode tertentu. Manajemen Data Grafik sangat diperlukan untuk menyusun laporan rekapitulasi kegiatan administratif desa yang dilakukan secara berkala.

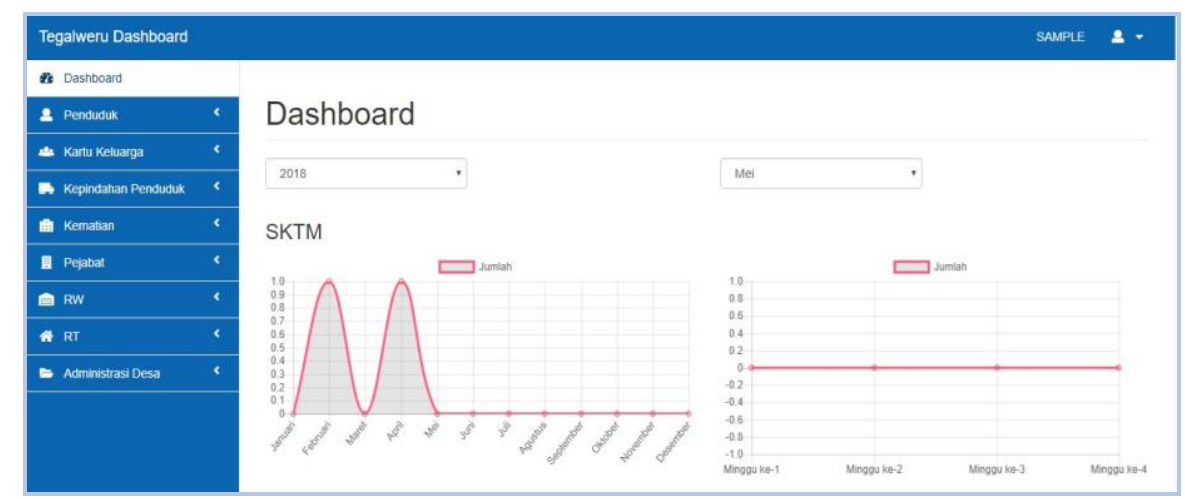




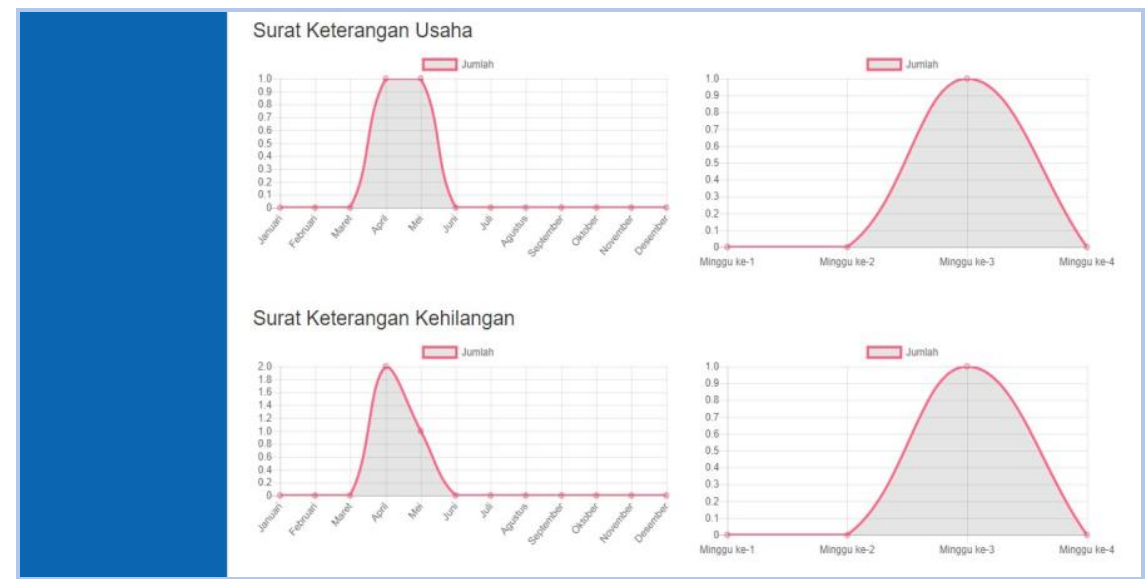

Gambar 4. Laman Manajemen Data Grafik

4. Menu Penduduk

Pengguna dapat melakukan beberapa aksi pada menu ini yang terkait dengan data penduduk, antara lain:

a. Melakukan pencarian data penduduk pada sub menu Data Penduduk melalui masukan kategori yang telah disediakan.

b. Menampilkan sekaligus melakukan penyuntingan detail data penduduk dan detail data Kartu Keluarga (KK) melalui masukan data nomor NIK dan nomor KK pada sub menu Data Penduduk.

c. Melakukan pengunduhan data penduduk dalam format pdf (.pdf) pada sub menu Data Penuduk.

d. Melakukan input data penduduk pada sub menu insert data penduduk.

e. Menampilkan statistik data penduduk dalam bentuk diagram pada sub menu Statistik Data Penduduk.

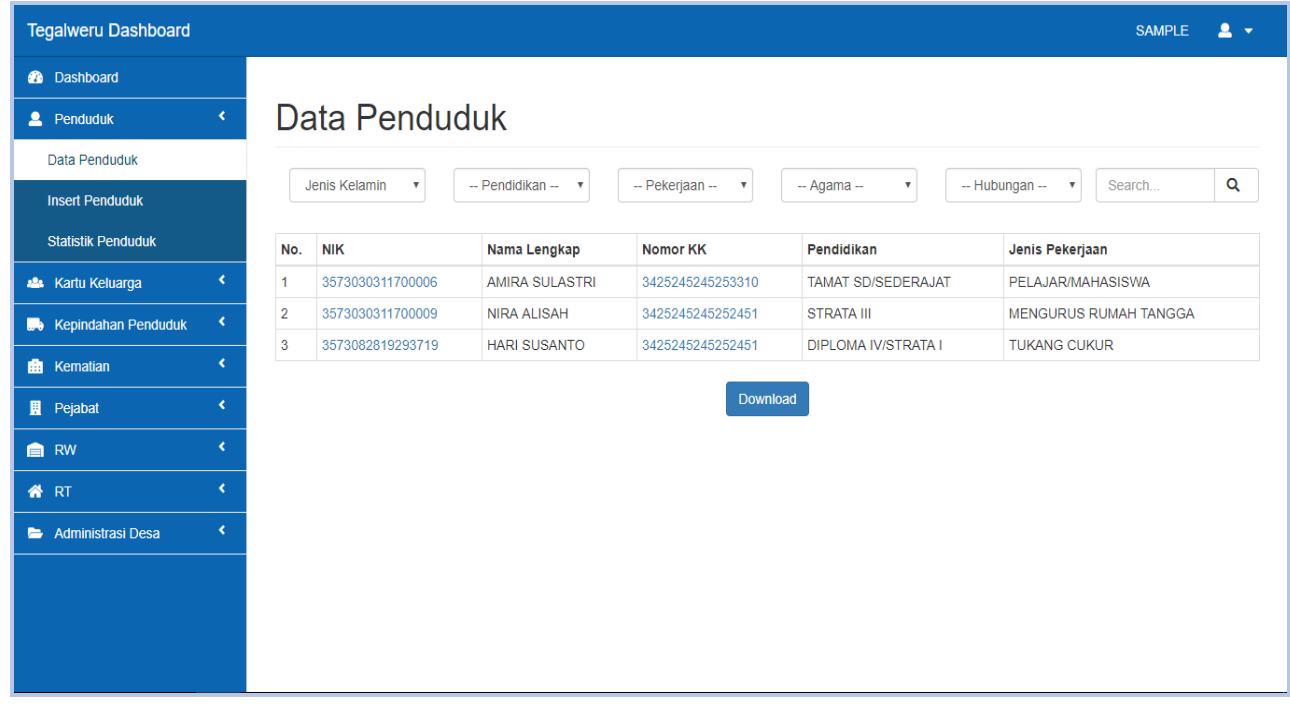

Gambar 5. Laman Manajemen Data Penduduk 
5. Menu Kartu Keluarga

Menu ini berfungsi untuk melakukan pencarian yang beraitan dengan data kartu keluarga, diantaranya:

a. Pencarian data kartu keluarga pada sub menu Data Kartu Keluarga dengan melakukan penyaringan dari data masukan kategori RT dan RW.

b. Menampilkan dan menyunting terhadap detail data kartu keluarga dan detail data penduduk melalui masukan data nomor KK, dan NIK kepala keluarga jika terjadi kesalahan data pada sub menu Data KK.

c. Melakukan input data anggota keluarga baru.

d. Menampilkan statistik data kartu keluarga dalam bentuk diagram pada sub menu Statistik KK.

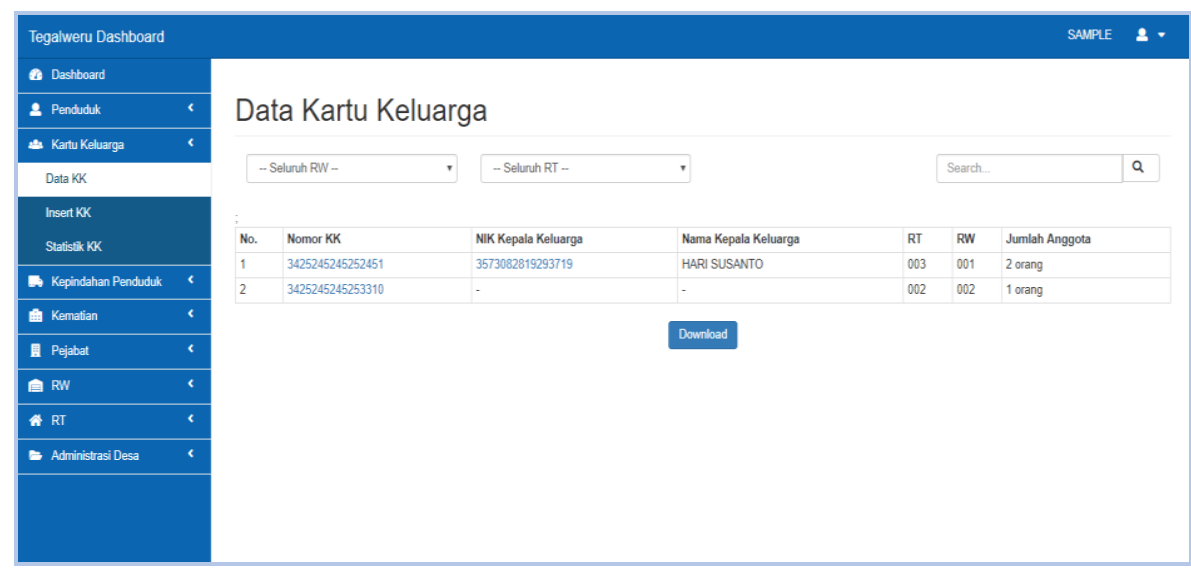

Gambar 6. Laman Manajemen Data KK

6. Menu Kepindahan Penduduk

Menu kepindahan penduduk berfungsi untuk melakukan pencarian menampilkan, menyuting, dan memasukkan data kepindahan pendudukan sesuia dengan NIK.

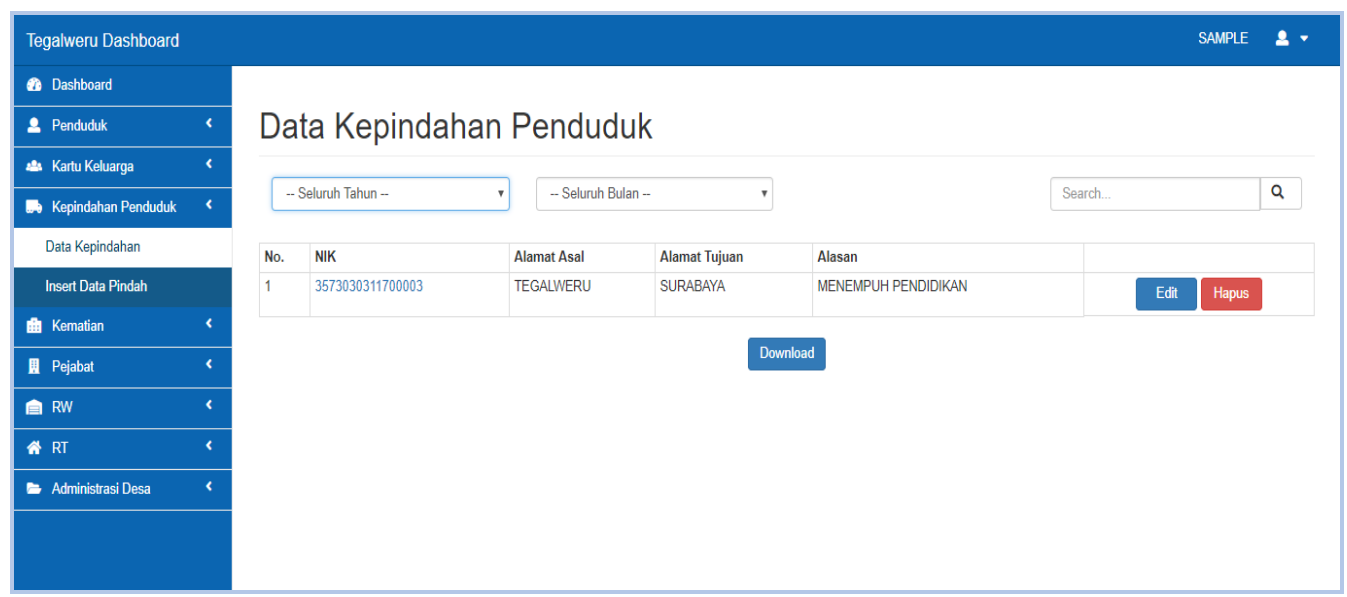

Gambar 7. Laman Manajemen Pindah Penduduk 
7. Menu Kematian

Pada menu kematian, pengguna dapat melakukan beberapa aksi yang terkait dengan data kematian penduduk, antara lain:

a. Menampilkan dan melakukan penyuntingan data detail penduduk melalui masukan data nomor NIK pada sub menu Data Kematian.

b. Melakukan penyuntingan dan penghapusan data kematian penduduk pada sub menu Data Kematian.

c. Mengunduh data kematian penduduk dalam format pdf (.pdf) pada sub menu Data Kematian.

d. Melakukan input data kematian baru.

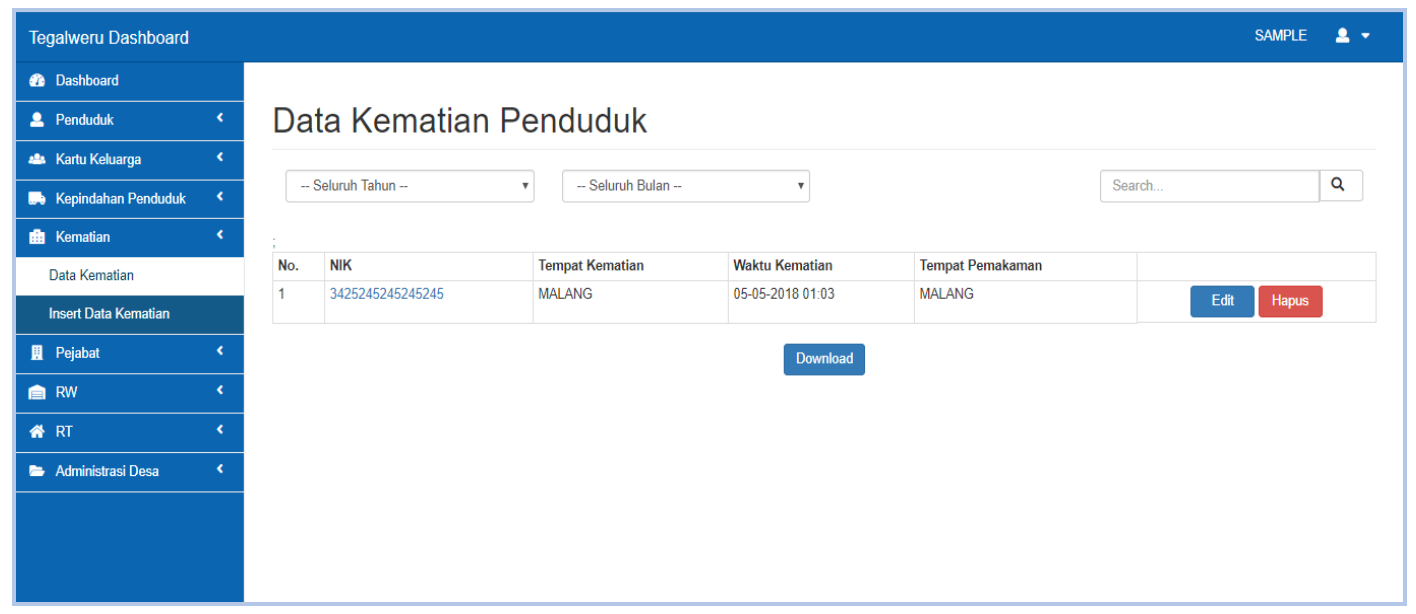

8. Pejabat

Gambar 8. Laman Manajemen Data Kematian

Pada menu Pejabat, pengguna dapat melakukan penyuntingan, penghapusan, dan input data pejabat desa baru.

9. Rukun Warga (RW)

Pada menu Rukun Warga, pengguna dapat melakukan penyuntingan dan penghapusan data RW juga memasukkan data RW baru.

10. Rukun Tetangga (RT)

Pada menu Rukun Tetangga, pengguna dapat melakukan penyuntingan dan penghapusan data RT, serta melakukan input data RT baru.

11. Administrasi Desa (Surat Keterangan)

Fitur utama menu ini dirancang untuk menghasilkan beberapa surat meliputi SKTM, SK Usaha, SK Kehilangan, SK Lahir, SK Dukun, SK Wali Nikah, SK 
Pelunasan PBB, serta SKKB. Pada menu ini, pengguna dapat melakukan beberapa aksi seperti:

a. Melakukan pencarian data SK dengan memfilter pada kategori tahun dan bulan.

b. Pengguna bisa memilih untuk menampilkan, melakukan penyuntingan, dan mengunduh data detail SK secara perorangan maupun keseluruhan dalam format pdf (.pdf) pada sub menu Data SK.

c. menambahkan data SK baru.

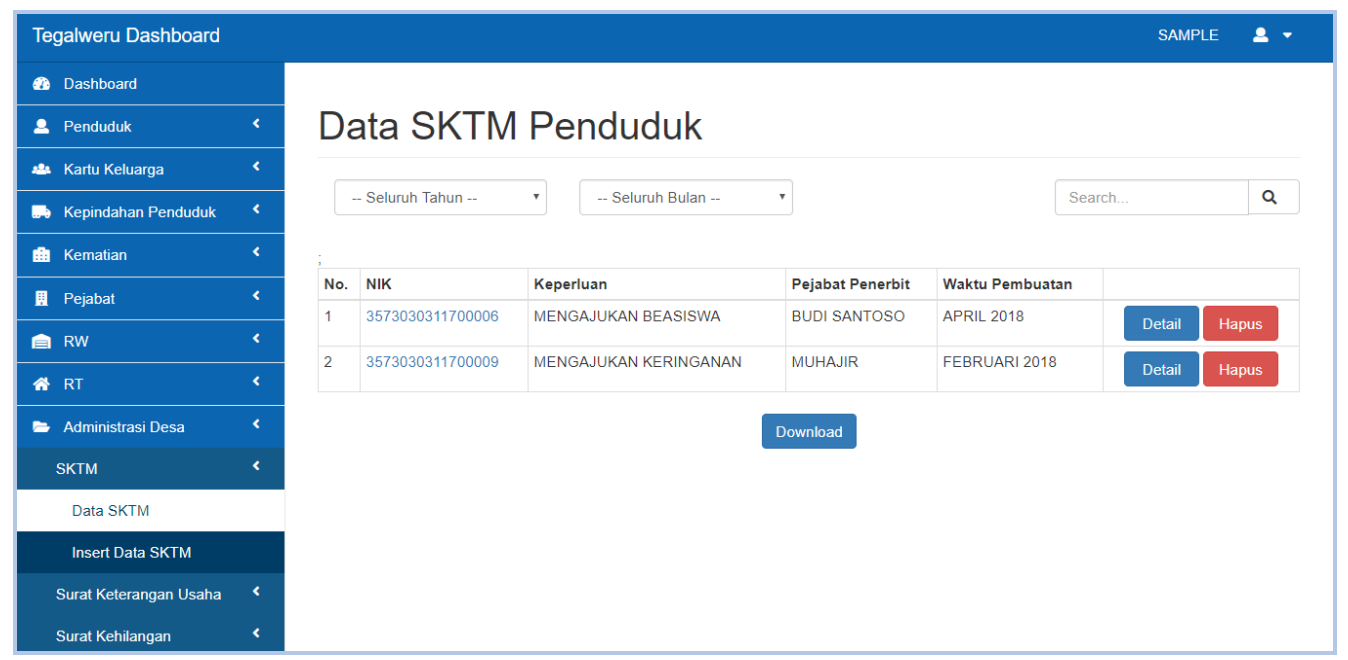

Gambar 9. Laman Administrasi SKTM

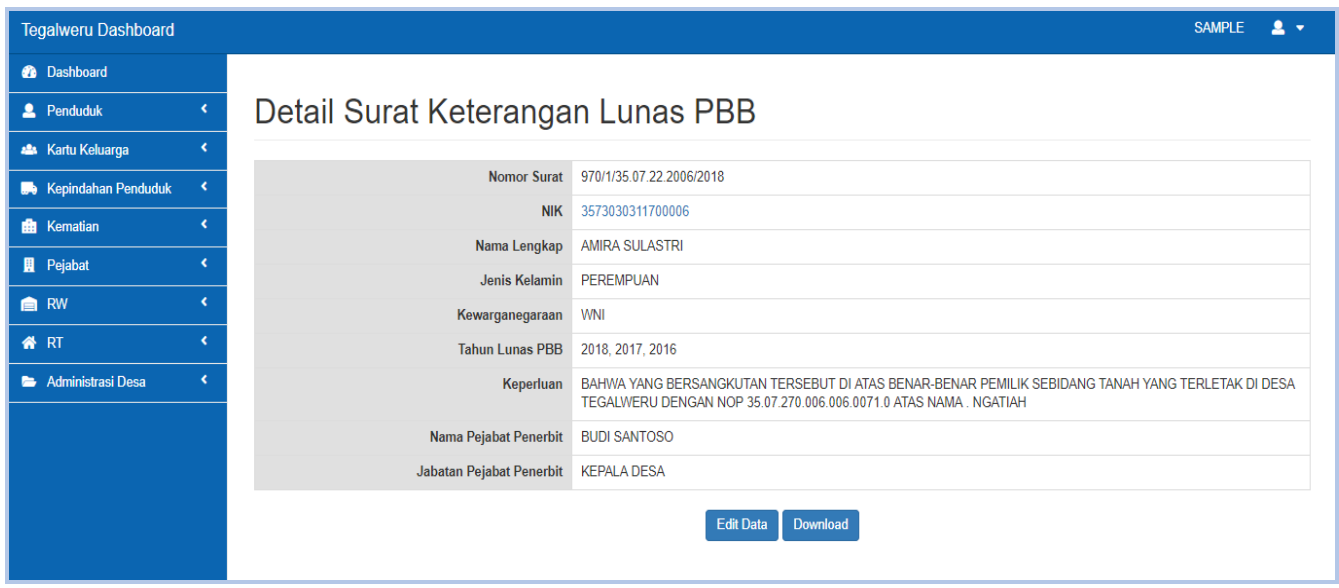

Gambar 10. $\quad$ Laman Administrasi SK Pelunasan PBB

Perancangan aplikasi akan menjadi solusi terbaik jika dilengkapi dengan pembekalan materi yang cukup kepada para perangkat desa, sehingga sistem informasi yang dikembangkan memiliki efektifitas yang baik (Wiguna, Yuniarta, \& Prayudi, 2018). Hal ini juga merupakan bagian dari strategi usaha untuk memaksimalkan manfaat dari penerapan teknologi informasi bagi masyarakat desa Tegalweru (Hartoyo \& Merdekawati, 
2016). Sehingga pada akhir kegiatan pengabdian masyarakat ini diselenggarakan pelatihan dan pembinaan teknis terhadap penggunaan aplikasi hingga akhir tahun 2019.

\section{KESIMPULAN}

Sistem Informasi Administrasi Desa yang dirancang dan dikembangkan sudah berfungsi sesuai dengan spesifikasi yang diharapkan. Desain aplikasi yang dirancang juga sesuai dengan proses bisnis yang ada Di Desa Tegalweru sehingga dapat langsung diterapkan tanpa harus menambah atau merubah standar operasional prosedur yang sudah ada. Layanan administrasi desa Tegalweru kepada masyarakat mengalami peningkatan yang baik terutama dari sisi dokumentasi dan rekapitulasi data surat masuk dan surat keluar, serta mendapatkan tanggapan yang positif dari perangkat dan masyarakat desa setempat.

\section{UCAPAN TERIMA KASIH}

Ucapan terima kasih terutama ditujukan kepada Lembaga Penelitian dan Pengabdian Kepada Masyarakat (LPPM) Universitas Ma Chung Malang sebagai pemberi dana kegiatan pengabdian kepada masyarakat ini.

\section{DAFTAR PUSTAKA}

Andoyo, A., \& Sujarwadi, A. (2017). Sistem Informasi Berbasis Web Pada Desa Tresnomaju Kecamatan Negerikaton Kab. Pesawaran. Jurnal TAM (Technology Acceptance Model), 3, 1-10.

Anwar, M., \& Pratolo, S. (2013). Peran Sistem Informasi yang Didukung Teknologi Informasi dalam Optimasi Pengelolaan Keuangan Desa Melalui Workshop Sistem Informasi Keuangan Desa (Sikades):(Studi pada Aparatur Desa Se-Kabupaten Indragiri Hilir). Akmenika: Jurnal Akuntansi Dan Manajemen, 10(1).

Badri, M. (2016). Pembangunan Pedesaan Berbasis Teknologi Informasi Dan Komunikasi (Studi Pada Gerakan Desa Membangun). Jurnal Dakwah Risalah, 27(2), 62-73.

Butt, S. M., \& Ahmad, W. F. W. (2012). Role of User and HCI in Software Development. International Journal of Computer Applications, 58(7).

Hartoyo, N. M., \& Merdekawati, I. (2016). Citalinuabdi: Upaya Membangun Sistem Informasi Desa Yang Bermakna. Jurnal Komunikasi Ikatan Sarjana Komunikasi Indonesia, 1(1), 48-57.

Jogiyanto. (2017). Analisis dan desain, Sistem Informasi: Pendekatan terstruktur Teori dan Praktek Aplikasi Bisnis. Yogyakarta: Andi Offset.

Ladjamudin. (2013). Analisis dan Desain Sistem Informasi. Yogyakarta: Graha Ilmu. 
Majid, R. A., Noor, N. L. M., Adnan, W. A. W., \& Mansor, S. (2010). A survey on user involvement in software development life cycle from practitioner's perspectives. In Computer Sciences and Convergence Information Technology (ICCIT), 2010 th I.

Mulyanto, A. (2009). Sistem Informasi Konsep dan Aplikasi. Yogyakarta: Pustaka Pelajar.

Peraturan Pemerintah, P. Peraturan pelaksanaan Undang-Undang Nomor 4 Tahun 2014 tentang Desa. , (2016).

Pressman, S., \& Roger. (2012). Rekayasa Perangkat Lunak Pendekatan Praktisi Buku1 dan 2 (Andi, Ed.). Yogyakarta.

Rusmayanti, A. (2013). Sistem Informasi Pengelolaan Keuangan Pada Desa Ngadirejan. Speed-Sentra Penelitian Engineering Dan Edukasi, 6(2).

Sommerville, I. (2011). Software Engineering (9th Edition). USA: Pearson Education.

Sutjianto, I. S., Noertjahyana, A., \& Rostianingsih, S. (2017). Perancangan dan Pembuatan Sistem Administrasi Pada Toko kiddy Baby Shop. Jurnal Infra, 5(1), 234-238.

UUD NO. 6 Tahun 2014, U. U. Undang-undang Republik Indonesia No 6 Tahun 2014 tentang Pemerintahan Desa.

Wiguna, I. M. D. P. D., Yuniarta, G. A., \& Prayudi, M. A. (2018). Pengaruh Kualitas Sumber Daya Manusia, Pendidikan Dan Pelatihan, Serta Peran Pendamping Desa Terhadap Efektivitas Penggunaan Sistem Keuangan Desa (Siskeudes)(Studi Pada Desa Penerima Dana Desa Di Kabupaten Buleleng). JIMAT (Jurnal Ilmiah Mahasiswa Akuntansi) Undiksha, 8(2). 